\title{
The Impact of Jigsaw and Listen-and-do Tasks on English for Specific Purposes (ESP) Learners' Reading Comprehension and Translation in Psychology Course
}

\author{
Somayeh Sahebalzamani ${ }^{1}$, Mohammad Golshan, Ph.D.* \\ *Assistant Professor of TEFL, Azad University, Maybod Branch, Iran \\ ${ }^{1}$ Ph. D. Student, Azad University, Maybod Branch, Iran
}

*Corresponding Author: Mohammad Golshan, Ph.D., Assistant Professor of TEFL, Azad University, Maybod Branch, Iran. Email: mohamadgolshann@gmail.com

\begin{abstract}
To find out adequate convenient methods and tasks for reading comprehension and translation has been the debate of many studies for several decades. The present study was an effort to examine the effects of jigsaw (cooperative learning) and listen-and-do tasks on English for Specific Purposes (ESP) students' reading comprehension and translation. Based on convenient sampling, the subjects of the study constituted 48 male and female, aged 21 to 25, of fourth semester Applied Science and Technology University Students in Psychology course. Then a Preliminary English Test (PET) was administered to find out the homogeneity of participants. They were divided into experimental groups-experimental 1 and experimental 2. After running pretests, group one was received jigsaw reading tasks, and group two was exposed to listen-and-do tasks during 8 sessions. Posttests were conducted immediately after treatment. An Independent samples and Paired samples t-test were run to analyze the data. The results demonstrate that jigsaw group outperformed listenand-do group in both reading comprehension skill and translation efficiently.
\end{abstract}

Keywords: cooperative learning, jigsaw task, listen-and-do task, reading comprehension and translation.

\section{INTRODUCTION}

In the quest of attaining developed educational system both in schools and universities, different methods and tasks have been conducted in many foreign and second language contexts specifically in the area of reading comprehension skill. At the age of communication and globalization, the society needs more educated and talented people. And also, learners need to know to acquire collaborative system in the role of cooperation and participation in learning and teaching. Collaborative learning situations are as the result of constructing shared mental model, Brown (1995). Cooperative learning such as doing jigsaw task and listening task are the most important approaches in teaching English as a Foreign Language (EFL) environments.

Slavin (1983) describes cooperative learning as students working in small groups and are given rewards and recognition based on the group's performance. A definition on cooperative learning as a category under collaborative learning is given by Goodsell, Maher and Tinto (1992). They demonstrate that cooperative learning which falls in the more general category of collaborative learning, which is described as students in groups of two or more, working together mutually to find an understanding, solutions or meaning and create a product.

Also, the process of listening in a second or foreign language is quite complex and can be done in a cooperative or no cooperative situation. As Rost (1990) notes, listening encompasses receptive, constructive, and interpretive aspects of cognition, which are utilized in both first language (L1) and second language (L2) listening" (p. 503).

\section{LITERATURE REVIEW}

\section{Task Types and Their Characteristics}

As Prabhu (1987) indicates, there are three major types of tasks according to the type of cognitive activity involved. They are; information-gap tasks, reasoning gap tasks and jigsaw tasks. 
In TBLT literature, there are many kinds of task categories since TBLT has been considering a vogue in language teaching field; writers have studied it from different outlooks. The Bangalore project, one of the earliest curricular applications of TBLT, provides three principal task types: information gap, reasoning gap, and opinion gap. Another typology that appeared almost at the same time was proposed by Pattison as' questions and answers, dialogues and role plays, matching activities, communication strategies, pictures and picture stories, puzzles and problems and discussions and decisions (Nunan, 2006, p.56).

Willis (1996) proposed six task types termed: listing, ordering, sorting, comparing, problem solving, sharing personal experiences, and creative tasks (Richards \& Rodgers, 2001, p. 234). Lately, Richards $\&$ Rodgers (2001) have proposed five pedagogical tasks, namely, jigsaw tasks; information-gap tasks; problem-solving tasks; decision-making tasks, and opinion exchange tasks (quoted in Nunan, 2006, p. $58)$.

Robinson (1991) looked at task characteristics differently and suggested three groups of factors that are important in designing tasks. He distinguished "task complexity that depends on cognitive demand of tasks", "task difficulty that depends on learner factors such as aptitude, confidence, motivation, etc., and "task conditions that depends on the interactive demands of tasks" , such as familiarity of participants and whether tasks demand one-way or two-way information exchange (p. 287). $\mathrm{He}$ argues that these factors influence task performance and learning. Since tasks have been classified into various categories, it is necessary to know how to compare them.

Pica et al (1989, cited in Khoshsima and Saed, 2016) propose that tasks are distinct from or connected with regard to the following features: 1) One-way or two-way: whether there is mutual exchange of information among participants when tasks are carried out. 2) Convergent or divergent: whether participants achieve the same goal or different goals. 3) Collaborative or competitive: whether participants carry out a task in a cooperative or competitive fashion. 4) Single or multiple outcomes: whether there is only one or multiple outcomes are possible. 5) Concrete or abstract language: whether the language used in the task is concrete or abstract. 6) Simple or complex processing: whether it is required a simple or complex cognitive process to complete a task. 7) Simple or complex language: whether task completion requires simple or complex language use. 8) Reality-based or not reality-based: whether the task related to real-life tasks (Richards \& Rodgers, 2001, p. 235).

\section{RESEARCH ON TBLT}

"Tasks do not take place in a vacuum; nevertheless, until recently, much of the task-based learning and teaching literature has had a tendency to treat them as if they did. Few studies have taken place in intact classes (Samuda, 2001). Yuan and Ellis (2003) conduct a study concerning the effect of time limit of a task on learners' performance in terms of their linguistic complexity and accuracy. The results show that learners who are given unlimited time to perform are required to perform the same task under time pressure (quoted in, 2006, p. 27).

Foster and Skehan (1999) investigated the influence of task types and task planning on linguistic fluency, accuracy and complexity. They found that planning influences learners outcome in terms of fluency and complexity, but not on accuracy (Oxford, 2006).

Ellis and Heimbach (1997) investigate the relation between meaning negotiation and comprehension, demonstrating that the task with opportunity to interaction facilitates children's understanding. As cited in Ellis (2003), "Ellis (1994) investigate the influence of different types of task input on comprehension of directives containing target words. The results of this study showed that learners receiving modified input outperform their counterpart with simplified input on vocabulary acquisition", (p.60). Newton (1993, quoted in Ellis, 2003, p.87) has gone to a step further and has compared the impact of different types of task on vocabulary acquisition, demonstrated that a split information task results in more vocabulary gain.

\subsection{Listening Comprehension}

Ellis (2003) states that there are two aspects of listening, listen to comprehend and listen to notice in the form of reciprocal and non-reciprocal. Reciprocal task refers to a two-way flow of information between a speaker and a listener like giving the direction task, while in one-way non-reciprocal tasks learners listen to the text without any opportunity to interact like listen-and-do tasks. 
Listening involves bottom-up processing, in which listeners use their linguistic knowledge of sounds, word forms and grammatical relationships to comprehend input, as well as top-down processing, where prior experience, schematic and contextual knowledge or familiarity with the listening context help the listeners to interpret an utterance (Peterson, 2001).

In studying listening comprehension, many researchers focus on input processing based on Anderson's (1985, cited in O'bryan, 2010) three-phase comprehension model: perceptual processing, parsing and utilization. Anderson notes that these phases are ordered, by necessity, in time but also partly overlap. In the perceptual stage, the learner recognizes sounds and segments those sounds into words. These words are accessed by various clues, including the identification of phonemes and recognition of word boundaries and syllable stress (Rost, 2002). In the parsing stage, listeners assign recognized words into grammatical categories and assign structural and semantic relations. These words are then transformed into a mental representation of the combined meaning of words; this information is moved to long-term memory and stored as propositions. Once a sentence or utterance has been parsed and mapped into a meaning representation, learners in the utilization stage begin making connections between this newly-parsed information and the knowledge they have about the world.

Ellis (2003) argues that lexical, and even semantic chunking increases the salience of input by allowing learners to activate associated "meaning representations" (p. 78); this, in turn, facilitates parsing, a crucial phase in the listening comprehension process. Therefore, providing repeated input through structured repetition could both enhance recall and burden comprehension processes by raising understandability, making input salient, and assisting learners in making mental representations of the input through structure building.

Ellis and Sinclair (1996, cited in O'bryan, 2010) provide empirical finding that language learners who were forced to rehearse, or repeat, Welsh utterances demonstrated "superior performance in receptive skills in terms of learning to comprehend and translate [foreign language] words and phrases" (p. 243) when compared to learners who were prevented from articulating the same utterances. While it was unclear whether the advantage of repetition in this study lay in the articulation of the utterances, or the students' hearing of their own repetitions, the authors conclude that "short-term representation and rehearsal allows the eventual establishment of long-term sequence information for language" (p. 247).

\subsection{Reading Comprehension}

Richard, Platt and weber (1985) define reading comprehension as the understanding that results from perceiving a written text. There are different types of reading comprehension distinguished according to the reader's purpose in reading: literal comprehension, inferential comprehension, critical comprehension and appreciative comprehension. (p.238)

Many studies have investigated the effect of various reading methods and techniques on reading comprehension (Abdel-Rehim, 1995; Fowler, 1993; Blue, 1992; Culver, 1991; Wang \& Qi, 1991).

The increasing tendency to make use of cooperative learning techniques in reading instruction has resulted in a number of studies adopting such techniques. Some of these studies investigated the effect of the Jigsaw Reading technique as one that maximizes the interactive basis of cooperative learning. Epstein (1991) examined the efficacy of this technique and asserted the advantages of cooperative learning that this technique provides, it increases the student independence, avoids dominance by one group member, creates peer acceptance and understanding, promotes individual and group responsibility and develops social skills. These results were also affirmed by the studies of Draper (1997), and Graney (1989). This characterizes the Jigsaw Reading technique as a communicationbased and trust-building one. But, in spite of all the advantages attributed to this technique, its contribution to EFL reading instruction is somehow controversial, since it may, as Berkeley-Wykes (1983) points out, lead to some sort of confusion among the readers. This confusion appears when the readers fail to restore the text to its proper order; something that overshadows what can be achieved through this technique.

Due to the emergence of communicative approaches we have task - based language teaching and as Willis (1996) pointed out it is the development of communicative language teaching. It is believed that task provide learners with a natural context (Nunan, 1989). Task gives abundant opportunity of 
interaction to learners and through which they learn language (Freeman, 2003). Despite the fact that many tasks have been designed for pedagogic purposes, it is only in recent years that language teaching studies have shown tendency in working what kinds of tasks can improve language learning process.

The study of Chalak (2015) focus on improving reading comprehension ability through Task-based Instruction (TBI). The participants of the study were 135 Iranian female students at different levels selected from high schools in Isfahan, Iran. The findings suggest that using flexible and interactive tasks in English classes improves reading comprehension ability of Iranian EFL learners.

\subsection{Jigsaw Reading}

Berkeley-Wykes (1983) defines the Jigsaw Reading technique as the technique in which a reading text is cut into segments and the task of the students is to restore it to its proper order - to make sense of the text. If used as a group activity where students discuss the decisions of how to order the segments of the text, it can elicit a great deal of communicative interaction (p. 314).

Khoshnam and Saed (2016) investigate Iranian intermediate EFL learners' vocabulary learning within the paradigm of Task Based Language Teaching through instructing jigsaw and information-gap tasks. The results indicate that TBI had a significant effect $(p=.000)$ on promoting vocabulary knowledge of Iranian intermediate EFL learners; there existed a significant difference between the experimental groups' performances in the assigned tests, as well.

Although many studies have mentioned the impact of cooperative and listening on reading comprehension and translation, they have not worked on ESP courses through jigsaw and listen-anddo tasks anymore. The present study endeavors to find out the effect of jigsaw task and listen-and-do task on ESP university students' reading comprehension and translation by answering these research questions:

1) What kind of task jigsaw or listen-and-do is more efficient in reading comprehension?

2) What kind of task jigsaw or listen-and-do is more efficient in translation?

\section{Methodology}

The pretest-posttest design study was performed with two intact groups of 24 ESP intermediate psychology students in Applied Science and Technology University in Kerman, Iran. They were selected based on convenient sampling from the population of $(\mathrm{N}=48)$. The subjects were male and female ranging from 21 to 25 . English proficiency level of participants was modified with the Preliminary English Test (PET). After running 2 pretests in the form of translation and reading comprehension, experimental group one was received jigsaw tasks, experimental group two was exposed to listen-and-do tasks during 8 sessions in 90 minutes.

\section{Procedure and materials}

Before giving treatments, 2 piloted pretests (Cronbach $\alpha=0.81$ ) were conducted among 48 participants during two sessions. All the tests were selected from English for the Students of Psychology textbook by (Rastegarpour, 2015).

The first version of pretest was conducted for reading comprehension in the form of 20 fill in the blanks, true/false, multiple choice and close ended questions, (Appendix A). The score of this pretest was from 1 to 20 .

Second version of pretest was run in the form of translation task. Students were given the text, they had to read and translate it into Persian in 30 minutes, (Appendix B). The assessment criteria for giving score 1 to 20 to the learners' translation task were based on (a) semantical writing and meaningful translation, (b) correct use of verb tenses and (c) correct punctuations.

After conducting pretests, experimental group one was received jigsaw tasks in the form of Psychological texts (about different branches of psychology, modern and traditional psychology, different characteristic of people and ...) which were segmented by the researcher before the class. In each ninety-minute session during the following phases: 
Phase (1): 24 participants were divided into 4 groups of 6 members by the teacher.

Phase (2): Each group was received one part of the information about the text. They had to read, discuss, paraphrase and translate it in 20 minutes. (There was an interaction between group members).

Phase (3): All the leaders of each group had to explain about their topic for all students in 15 minutes. There was an interaction with the whole class.

Phase (4): The teacher and students discussed, cooperated and interacted together to clarify and to elaborate the whole text in English and Persian during 20 minutes.

Phase (5): The teacher read all paragraphs and translated them into Persian generally not sentence by sentence and in 15 minutes.

Phase (6): Then the teacher gave them the comprehension questions in the form of fill in the blanks, true/false, multiple choice and close ended questions to do. After that all the class check their answers in the last 20 minutes.

During all phases the teacher's guide, help and control were very important and crucial.

Experimental group two was exposed to the listen-and-do task each session in the following phases:

Phase (1): The teacher gave the students a handout with the same texts and topics as the experimental group one. But it was not divided. It was given as a whole text. The learners had to read and understand it in 10 minutes.

Phase (2): The teacher read the text aloud or played the recorded sound by herself and learners just listened. After that the teacher paraphrased and translated the text into Persian paragraph by paragraph through giving pre modified and baseline input and students took notes without any opportunity to interact with each other during 50 minutes.

Phase (3): Then the teacher gave them the comprehension questions in the form of fill in the blanks, true/false, multiple choice and close ended questions to answer. After that all the class checked their answers with each other and with the teacher in the last 30 minutes.

After finishing treatment sessions, the piloted immediate posttests (Cronbach $\alpha=0.83$ ) in the form of comprehension and translation like pretests were conducted during two sessions.

\section{RESUlts}

In order to answer the questions of this study and analyze the scores on pretests and immediate posttests by both experimental groups, the SPSS 22 was used. Later, the possible differences in the performance of two groups were examined through An Independent and Paired samples t-test.

Table1. Descriptive Statistic for Pretests

\begin{tabular}{cccccccc} 
& Groups & Tests & $\mathrm{N}$ & Mean & SD & Min & Max \\
\hline Pretest & Group1 & reading & 24 & 6.89 & 3.41 & 1.00 & 12 \\
\cline { 2 - 8 } & Group1 & translate & 24 & 6.84 & 3.55 & 1.00 & 14 \\
\hline & Group2 & reading & 24 & 7.28 & 3.26 & 2.00 & 13 \\
\hline & Group2 & translate & 24 & 7.18 & 3.23 & 1.00 & 13
\end{tabular}

Table 1 shows the initial 24 subjects of jigsaw group (group1) obtained minimum score of 1 and maximum score of 12 out of 20 and mean score $M=6.89$ with $S D=3.41$ from reading comprehension test and they had the minimum score of 1 and maximum score of 14 out of 20 and mean score $M=6.84$ with $S D=3.55$ from translation exam. Also, the minimum score of 2 and maximum score 13 out of 20 with mean score $M=7.28$ and $S D=3.26$ were analyzed for 24 subjects in listen-and-do group (group2) in reading comprehension test and the minimum score of 1 and maximum score 13 out of 20 with mean score $M=7.18$ and $S D=3.23$ for translation in pretest.

Table2. Descriptive Statistic for Posttests

\begin{tabular}{cccccccc} 
& Groups & Tests & $\mathrm{N}$ & Mean & SD & Min & Max \\
\hline Posttest & Group1 & reading & 24 & 15.10 & 2.34 & 10.00 & 20 \\
\cline { 2 - 9 } & Group1 & translate & 24 & 15.56 & 2.77 & 11.00 & 19 \\
\hline Group2 & reading & 24 & 7.52 & 4.38 & 1.00 & 17 \\
\hline & Group2 & translate & 24 & 7.68 & 4.31 & 1.00 & 16
\end{tabular}


Table 2 demonstrates that in posttest time 24 participants in jigsaw group (group1) obtained minimum score of 10 and maximum score of 20 out of 20 and mean score $M=15.10$ with $S D=2.34$ from reading comprehension test and they had the minimum score of 11 and maximum score of 19 out of 20 and mean score $M=15.56$ with $S D=2.77$ from translation exam. Moreover, the minimum score of 1 and maximum score 17 out of 20 with mean score $M=7.52$ and $S D=4.38$ were analyzed for 24 subjects in listen-and-do group (group2) in reading comprehension test and the minimum score of 1 and maximum score 16 out of 20 with mean score $M=7.68$ and $S D=4.31$ for translation exam in posttest.

Table3. Paired Samples t-Test for Jigsaw Group (Reading Comprehension)

\begin{tabular}{|c|c|c|c|c|c|c|c|c|c|}
\hline & & \multicolumn{5}{|c|}{ Paired Differences } & \multirow[b]{3}{*}{$\mathrm{l}$} & \multirow[b]{3}{*}{ df } & \multirow{3}{*}{$\begin{array}{l}\text { Sig. (2- } \\
\text { tailed) }\end{array}$} \\
\hline & & \multirow[b]{2}{*}{ Mean } & \multirow{2}{*}{$\begin{array}{c}\text { Std. } \\
\text { Deviation }\end{array}$} & \multirow{2}{*}{$\begin{array}{l}\text { Std. Error } \\
\text { Mean }\end{array}$} & \multicolumn{2}{|c|}{$\begin{array}{c}95 \% \text { Confidence } \\
\text { Interval of the } \\
\text { Difference }\end{array}$} & & & \\
\hline & & & & & Lower & Upper & & & \\
\hline Pair 1 & Pretest - Posttest & -8.20833 & 4.24744 & .61307 & -9.44166 & -6.97500 & -13.389 & 47 & .000 \\
\hline
\end{tabular}

Table 3 compares the reading comprehension pre-test and post-test scores of group1 to find out any within group significant differences. Results show that in jigsaw group there was an increase in reading comprehension test from pretest time $(M=6.89, S D=3.41)$ to posttest time $(M=15.10, S D=$ 2.34), $t$ (-13.38), and sig (.000) at $p$-value <.01 (two-tailed). The mean increase in such task was 8.20 with a $95 \%$ confidence interval ranging from -9.44 to -6.97 with high effect size (eta squared $=.79$ ). The results show that the treatment was effective in reading comprehension rest of group 1.

Table4. Paired Samples t-Test for Jigsaw Group (Translation)

\begin{tabular}{|c|c|c|c|c|c|c|c|c|c|}
\hline & & \multicolumn{5}{|c|}{ Paired Differences } & \multirow[b]{3}{*}{$\mathrm{t}$} & \multirow[b]{3}{*}{$\mathrm{df}$} & \multirow{3}{*}{$\begin{array}{l}\text { Sig. (2- } \\
\text { tailed) }\end{array}$} \\
\hline & & \multirow[b]{2}{*}{ Mean } & \multirow{2}{*}{$\begin{array}{c}\text { Std. } \\
\text { Deviation }\end{array}$} & \multirow{2}{*}{$\begin{array}{l}\text { Std. Error } \\
\text { Mean }\end{array}$} & \multicolumn{2}{|c|}{$\begin{array}{c}95 \% \text { Confidence Interval } \\
\text { of the Difference } \\
\end{array}$} & & & \\
\hline & & & & & Lower & Upper & & & \\
\hline Pair 1 & Pretest - Posttest & -8.91667 & 4.53278 & .65425 & -10.23285 & -7.60048 & -13.629 & 47 & .000 \\
\hline
\end{tabular}

Table 4 demonstrates the significant difference between the scores of pretest time and posttest time in translation of jigsaw group. Findings in table 5 show that the scores within jigsaw group were increased in translation test from time $1(M=6.84, S D=3.55)$ to time $2(M=15.56, S D=2.77), t(-$ 13.62), and sig (.000) at $p$-value <.01 (two-tailed). The mean increase in such task was 8.91 with a $95 \%$ confidence interval ranging from -10.23 to -7.60 with high effect size (eta squared $=.79$ ). The results show the effectiveness of treatment in translation of this group.

Table5. Paired Samples $t$-Test for Listen-and-do Group (Reading Comprehension)

\begin{tabular}{|c|c|c|c|c|c|c|c|c|}
\hline & \multicolumn{5}{|c|}{ Paired Differences } & \multirow[b]{3}{*}{$\mathrm{t}$} & \multirow[b]{3}{*}{ df } & \multirow{3}{*}{$\begin{array}{l}\text { Sig. (2- } \\
\text { tailed) }\end{array}$} \\
\hline & \multirow[b]{2}{*}{ Mean } & \multirow{2}{*}{$\begin{array}{c}\text { Std. } \\
\text { Deviation }\end{array}$} & \multirow{2}{*}{$\begin{array}{l}\text { Std. Error } \\
\text { Mean }\end{array}$} & \multicolumn{2}{|c|}{$\begin{array}{l}95 \% \text { Confidence Interval } \\
\text { of the Difference } \\
\end{array}$} & & & \\
\hline & & & & Lower & Upper & & & \\
\hline Pair 1 Pretest - Posttest & -.25000 & 5.39700 & .77899 & -1.81713 & 1.31713 & -.321 & 47 & .750 \\
\hline
\end{tabular}

To compare the pretest and posttest scores of within listen-and-do group again paired samples $t$-test was run. Results in table 5 expresses that in listen-and-do group there was no increase in reading comprehension test from pretest time $(M=7.28, S D=3.26)$ to posttest time $(M=7.52, S D=4.38), t$ (-.32), and sig (.75) at $p$-value $<0.05$ (two-tailed). There is no differences between the pretest scores and posttest scores of this group. The mean decrease in such task was about .25 with a 95\% confidence interval ranging from -1.81 to -1.31 with low effect size (eta squared $=.002$ ). The results demonstrates no efficient treatment in this group in reading comprehension test.

Table6. Paired Samples t-Test for Listen-and-do Group (Translation)

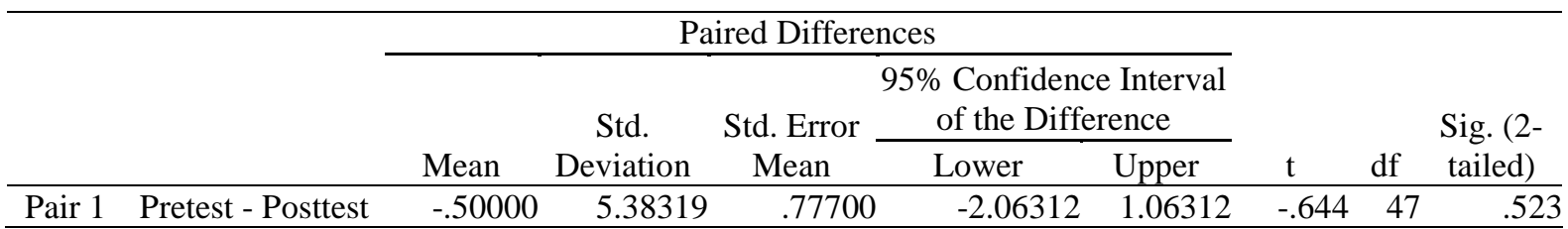


Table 6 demonstrates the results of pretest and posttest scores within the listen-and-do group in translation. There was no increase in translation test from pretest time $(M=7.18, S D=3.23)$ to posttest time $(M=7.68, S D=4.31), t(-.64)$, and sig (.52) at $p$-value $<0.05$ (two-tailed). There is not any differences between the pretest scores and posttest scores of this group. The mean decrease in such task was about .50 with a $95 \%$ confidence interval ranging from -2.06 to 1.06 with low effect size (eta squared $=.008$ ). The results demonstrates no efficient treatment in this group in translation test.

Table7. Independent Samples t-Test For Groups' Reading Comprehension Pretests

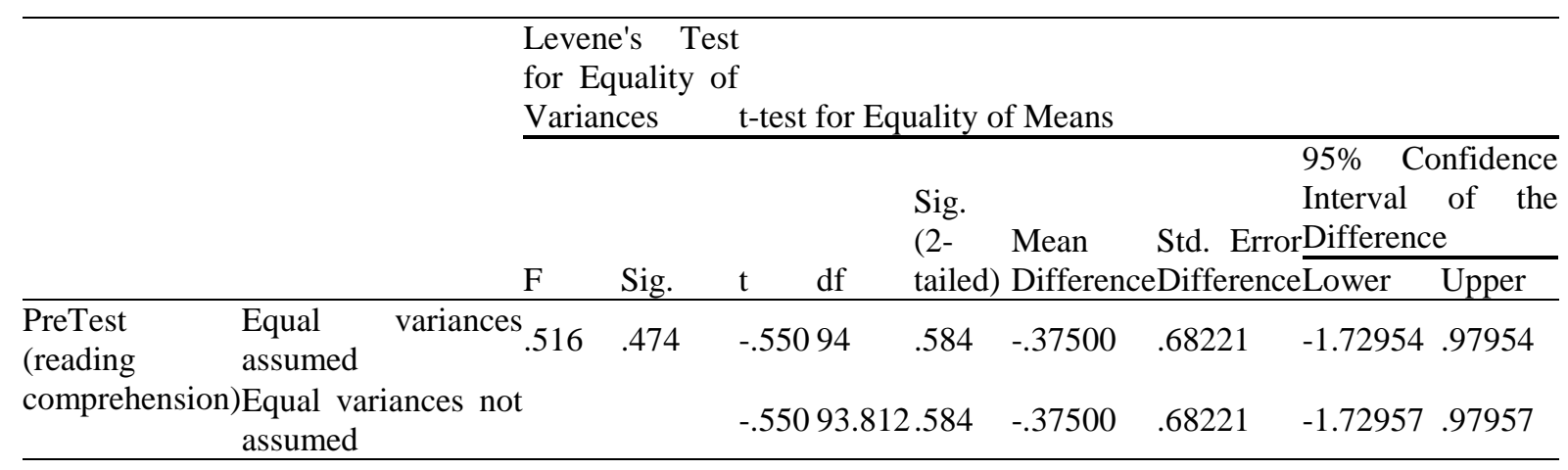

To find out any significant differences between the pretest scores of jigsaw group and listen-and-do group in reading comprehension, independent samples $t$-test was run. The results in table 7 show that there is not a significant difference in scores for jigsaw group $(M=6.89, S D=3.41)$ and listen-and-do group $(M=7.28, S D=3.26), t(-.55)=.47$ with $d f(94)$ and $p=.58$, two tailed. The magnitude of the differences in the means (mean difference $=.37,95 \%$ CI: -1.72 to .97 ) was very small (eta squared $=$ $.003)$.

Table8. Independent Samples t-Test for Groups’ Translation Pretests

\begin{tabular}{|c|c|c|c|c|c|c|c|c|c|}
\hline & $\begin{array}{r}\text { Levene's } \\
\text { for Equal } \\
\text { Varian } \\
\end{array}$ & $\begin{array}{l}\text { Test } \\
\text { ity of } \\
\text { ces } \\
\end{array}$ & \multicolumn{7}{|c|}{ t-test for Equality of Means } \\
\hline & \multirow[b]{2}{*}{$\mathrm{F}$} & \multirow[b]{2}{*}{ Sig. } & \multirow[b]{2}{*}{$t$} & \multirow[b]{2}{*}{ df } & \multirow{2}{*}{$\begin{array}{l}\text { Sig. } \\
(2- \\
\text { tailed) }\end{array}$} & \multirow{2}{*}{$\begin{array}{c}\text { Mean } \\
\text { Differencel }\end{array}$} & \multirow{2}{*}{$\begin{array}{l}\text { Std. Error } \\
\text { Difference }\end{array}$} & \multicolumn{2}{|c|}{$\begin{array}{c}95 \% \text { Confidence } \\
\text { Interval of the } \\
\text { Difference } \\
\end{array}$} \\
\hline & & & & & & & & Lower & Upper \\
\hline $\begin{array}{l}\text { PreTest Equal variances } \\
\text { (Translation)assumed }\end{array}$ & .237 & .628 & -.781 & 94 & .437 & -.54167 & .69391 & -1.91944 & .83611 \\
\hline $\begin{array}{l}\text { Equal variances not } \\
\text { assumed }\end{array}$ & & & -.781 & 3.215 & .437 & -.54167 & .69391 & -1.91959 & .83626 \\
\hline
\end{tabular}

To find out any significant differences between the pretest scores of translation of jigsaw group and listen-and-do group independent samples $t$-test was run. The results in table 8 show that there is not a significant difference in scores for jigsaw group $(M=6.84, S D=3.55)$ and listen-and-do group $(M=$ $7.18, S D=3.23), t(-.78)=.62$ with $d f(94)$ and $p=.43$, two tailed. The magnitude of the differences in the means (mean difference $=.54,95 \% \mathrm{CI}$ : -1.91 to .83 ) was very small (eta squared $=.006$ ).

Table9. Independent Samples t-Test for Groups' Reading Comprehension Posttests

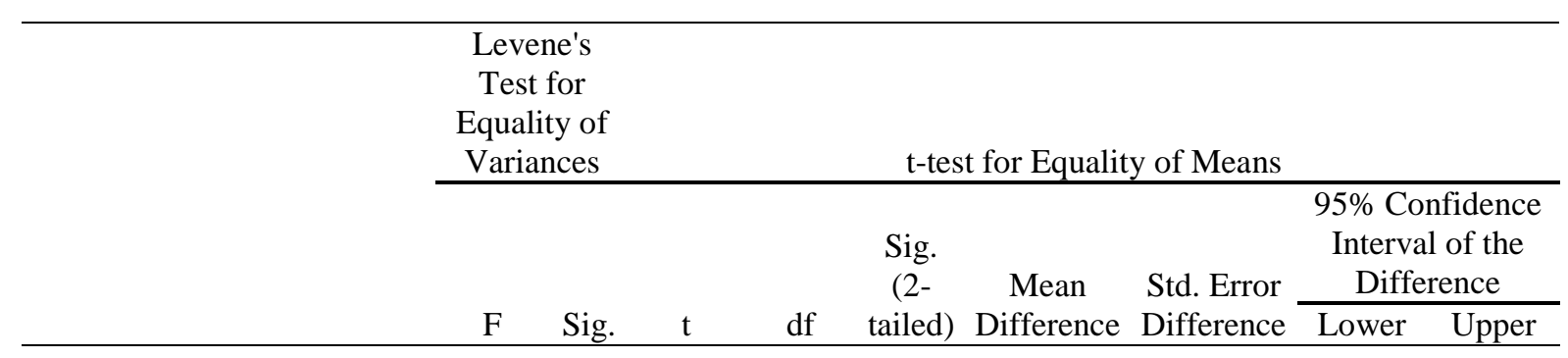


The Impact of Jigsaw and Listen-and-do Tasks on English for Specific Purposes (ESP) Learners' Reading Comprehension and Translation in Psychology Course

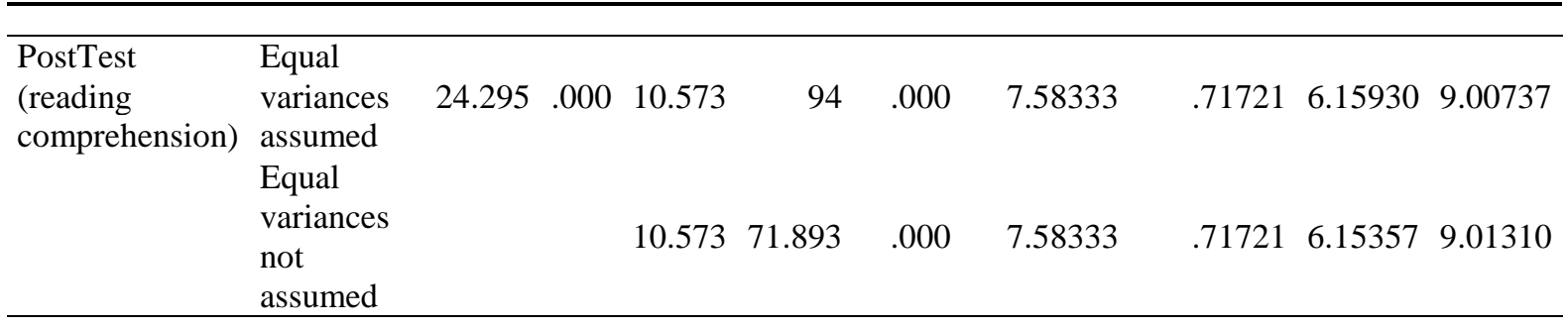

An independent-samples t-test was conducted to compare posttest scores of jigsaw group and listenand-do group in reading comprehension. There was a significant difference in scores for jigsaw group $(M=15.10, S D=2.34)$ and listen-and-do group $(M=7.52, S D=4.38), t(10.57)=.000$ with $d f(94)$ at $p$-value $<.01$, two tailed. The magnitude of the differences in the means (mean difference $=7.58$, $95 \%$ CI: 6.15 to 9.00 ) was high (eta squared $=.54$ ). It shows the effectiveness of jigsaw task in ESP students' reading comprehension test.

Table10. Independent Samples t-Test for Groups' Translation Posttests

\begin{tabular}{|c|c|c|c|c|c|c|c|c|}
\hline & $\begin{array}{r}\text { Levene's } \\
\text { for Equa } \\
\text { Varian }\end{array}$ & $\begin{array}{l}\text { Test } \\
\text { lity of } \\
\text { ces }\end{array}$ & & & \multicolumn{4}{|c|}{ t-test for Equality of Means } \\
\hline & \multirow[b]{2}{*}{$\mathrm{F}$} & \multirow[b]{2}{*}{ Sig. } & \multirow[b]{2}{*}{$\mathrm{t}$} & \multirow[b]{2}{*}{ df } & \multirow{2}{*}{$\begin{array}{l}\text { Sig. } \\
(2- \\
\text { tailed) L }\end{array}$} & \multirow{2}{*}{$\begin{array}{c}\text { Mean } \\
\text { Difference }\end{array}$} & \multirow{2}{*}{$\begin{array}{l}\text { Std. Error } \\
\text { Difference }\end{array}$} & $\begin{array}{l}95 \% \text { Confidence } \\
\text { Interval of the } \\
\text { Difference }\end{array}$ \\
\hline & & & & & & & & Lower \\
\hline $\begin{array}{l}\text { Posttest Equal variances } \\
\text { (Translation)assumed }\end{array}$ & 17.047 & .000 & 11.068 & 94 & .000 & 7.87500 & .71152 & 6.462269 .28774 \\
\hline $\begin{array}{l}\text { Equal variances not } \\
\text { assumed }\end{array}$ & & & 11.068 & 73.323 & .000 & 7.87500 & .71152 & 6.457059 .29295 \\
\hline
\end{tabular}

An independent-samples t-test was conducted to compare posttest scores of jigsaw group and listenand-do group in translation. There was a significant difference in scores for jigsaw group $(M=15.56$, $S D=2.77)$ and listen-and-do group $(M=7.68, S D=4.31), t(11.06)=.000$ with $d f(94)$ at $p$-value < .01 , two tailed. The magnitude of the differences in the means (mean difference $=7.87,95 \%$ CI: 6.46 to 9.28) was high (eta squared $=.56$ ). It shows the effectiveness of jigsaw task in ESP students' translation.

According to the findings of this paper and being in the line with the findings of some researchers (Berkeley-Wykes, 1983; Chalak, 2015; Fowler, 1993; Khoshnam and Saed, 2016) the researcher noticed that the mean scores of the experimental group 2 (listen-and-do) remained the same form the pretest to posttest, but in the experimental group 1 (jigsaw) was a great difference between pretest and posttest mean scores, therefore, it is concludes that collaborative learning and teaching such as doing jigsaw task improves learners' reading comprehension and translation especially in the area of English for specific purposes (ESP).

\section{DISCUSSION AND CONCLUSION}

To reveal appropriate methods and tasks for improving reading comprehension and translation has been the debate of many studies for several decades. The present study was an effort to test the effects of jigsaw (cooperative learning) and listen-and-do tasks on English for Specific Purposes (ESP) students' reading comprehension and translation. The observable difference in the effect of jigsaw task and listen-and-do task on learners' reading comprehension and translation was statistically significant. In other words, to answer the questions of this study whether the jigsaw and listen-and-do tasks have any impact on learners' reading comprehension and translation, the results of two posttests demonstrate that the experimental group one who was received jigsaw tasks outperformed the experimental group two who was exposed to the listen-and-do tasks with baseline and pre modified input in both reading comprehension test and translation. Although many studies (Berkeley-Wykes, 1983; Chalak, 2015; Draper, 1997; Ellis, 2003; Graney, 1989; and Khoshnam and Saed, 2016) have done on the impact of jigsaw task on learners' reading comprehension with the same findings as this study, none of them demonstrates the effect of jigsaw task on EFL learners' reading comprehension and translation in the English for Specific Purposes (ESP) course at universities. 
Based on the definition of collaborative learning by Goodsell, Maher and Tinto (1992), this study can demonstrate that cooperative learning in the form of jigsaw task which falls in the more general category of collaborative learning, which is described as students in groups of two or more, working together mutually to find an understanding, solutions or meaning and create a product is one of the best way of teaching and learning ESP texts. The contribution that this study makes to the existing literature is its finding that listen-and-do task may be effective as jigsaw task when there is a mutual interaction input from the teacher to the students. Also, reading comprehension can be improved through listening tasks but not in a one way task.

Single study investigations of any difference between jigsaw task and listen-and-do task are also needed to reveal new findings and implications in ESP course. Further researcher that includes in its design in different fields of ESP with different types of tasks and tests may show different findings. Despite positive findings in this study, some limitations need to be acknowledged. Because of the difficulty in accessing participants during one semester, the sample size was smaller than one would have wished for. Secondly, the study was conducted between both male and female, so the effect of gender differences on doing tasks didn't consider. Consequently, the findings of this study lead us to suggest that further research be conducted (1) to determine the effect of jigsaw task and listen and do task on learners' free recall writing, (2) to determine the effect of different tasks in the form of oneway or two-way on ESP learners' reading comprehension and translation and (3) to examine different ESP courses with different types of tests. Eventually, we believe that a number of pedagogical recommendations can be offered.

Firstly, findings in this study help ESP teachers to have a better view to using various types of methods to teach different types of texts in the classrooms. Secondly, these methods can be used to practice four language skills of writing, reading, speaking and listening. Thirdly, ESP material developers subsequently can benefit from the possible advantages endowed with presenting different activities and tasks. In addition, at the age of communication both students and teachers can have better understanding of the real situation and the real life interaction by using different styles through having intrinsic motivation towards English Language.

\section{REFERENCES}

[1] Abdel-Rehim, A.S. (1995). The effect of Metacognitive Strategies in Enhancing Reading. Comprehension Among Prospective Teachers of English. Unpublished Ph.D Dissertation, Al-Azhar Univ., Faculty of Education.

[2] Berkeley -Wykes, J. (1983). Jigsaw Reading. In Methods that Work .Eds: John W.Ollerc, Jr.,and Patricia A.Richard-Amato. Rowley: Newbury House publishers, Inc., pp.313-319.

[3] Blue, G. (1992). Reading in a Foreign Language: A Self-Access Approach. ERIC, 39, 22-40.

[4] Brown, G. (1995). Speakers, Listeners, and Communication. Cambridge: Cambridge University Press.

[5] Chalak, A. (2015). The effect of task-based instruction on reading comprehension of Iranian EFL Learners. Applied Research on English Language 4 (1), 19-29.

[6] Culver, L. C. (1991). Improving Reading Speed and Comprehension of ESL Students with the Computer. ERIC, 33, 59-60.

[7] Draper, R. J. (1997). Jigsaw: Because reading your math book should not be a puzzle. Reading Improvement, 71, 33-36.

[8] Ellis, N. (2003). Constructions, chunking, and connectionism: The emergence of second language structure. In C. Doughty \& M. Long (Eds.) The handbook of second language acquisition. Oxford: Blackwell Publishing.

[9] Ellis, R., \& Heimbach, R. (1997). Bugs and birds. Children's acquisition of second language Vocabulary through interaction. System, 25, 247-59.

[10] Epstein, R. (1991). Literacy through Cooperative Learning: the Jigsaw Reading Technique. ERIC, ED 43100.

[11] Flower, T. (1993). Fluency in Reading: Risk success. Reading Improvement, 30, 109-112.

[12] Foster, P., \& Skehan, P. (1999). The influence of planning and focus of planning on task-based performance. Language Teaching Research, 3, 215-47.

[13] Freeman, D. L. (2003). Techniques and principles in language teaching. Oxford: Oxford University Press. 
[14] Goodsell, A. Maher, M. and Tinto, V. (1992). Collaborative Learning: A Sourcebook for Higher Education. University Park, PA: National Centre on Postsecondary Teaching, Learning and Assessment.

[15] Graney, J. M. (1989). Providing Learning Opportunities Using Group Reading Activities. Guidelines: A Periodical for classroom Language Teachers, 2(1), 25.

[16] Khoshsima, H., \& Saed, A. (2016). Task-based Instruction and Vocabulary Learning: A Comparative Study of Jigsaw and Information Gap Tasks on Vocabulary Learning. International Journal of Applied Linguistics \& English Literature, 5(5).

[17] Kitao, K. (1994). Getting Students to Read Actively. Doshisha Studies in English, 63, 49-78.

[18] Nunan, D. (1989). Designing Tasks for the Communicative Classroom. Cambridge: Cambridge University Press.

[19] O'bryan, A. (2010). Investigating the impact of segmented and whole text repetition on listening comprehension, comprehension processes, and comprehension problems. Published dissertation in Iowa State University. Available in http://lib.dr.iastate.edu/etd

[20] Prabhu, N. S. (1987). Second Language Pedagogy. Oxford: Oxford University Press.

[21] Richard, J., Platt, J., and Weber, H. (1985). Longman Dictionary of Applied Linguistics. London: Longman.

[22] Rastegarpour, H. (2015). English for the students of psychology. Samt Publication, Iran: Tehran

[23] Rost, M. (1990). Listening in Language Learning. London; Longman

[24] Rost, M. (2002). Teaching and researching listening. Harlow: Pearson Education.

[25] Slavin, R.E. (1983). Cooperative Learning. New York: Longman

[26] Wang, Ch., \& Qi, L. (1991). EFL Reading Revisited: A Language Problem or a Reading Problem. ERIC, 23(5), 30 .

[27] Willis, J. (1996). A framework for task-based learning. Harlow: Longman

[28] Yuan, F., \& Ellis. R. (2003). The effect of pre-task planning and on-line planning on fluency, complexity and accuracy in L2 oral production. Applied Linguistics.

\section{AUTHORS' BIOGRAPHY}

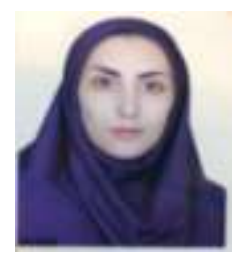

Somayeh Sahebalzamani, Ph.D. candidate at Azad university, Maybod branch, teacher of Payam Noor university and Applied Science University

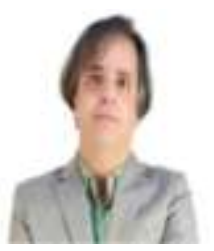

Mohammad Golshan, Ph.D., assistant professor of TEFL, faculty member of Azad University, writer of more than 40 books.

Some of his Books' names: Proposal and Thesis Writing Made Easy, Essential Text for Proposal and Thesis Writing in English,....

\section{APPENDiX A}

Read the text carefully and answer the question.

\section{Learning}

Learning is relatively permanent change in behavior due to pate experience. Notice that this definition excludes temporary changes by motivation, fatigue, maturation, disease, injury or drugs. Each of these can change behavior, but none constitutes learning.

At the beginning of the twentieth century, the Russian psychologist Ivan Pavlov brought international recognition of classical conditioning. Actually, he studied digestion. In order to observe salivation, he placed meat powder or some tidbit on a dog's tongue and measured the resulting flow of saliva. After a time, Pavlov began to notice that his animals were salivating before food was placed in their mouths. Later, the dog began to salivate at the mere sight of Pavlov entering the room. He realized that this was something more than misplaced affection. Salivation is normally a reflex (automatic, unlearned) response. Some kind of learning had to place for the animals to salivate when they saw 
Pavlov. He called this form of learning conditioning. Because of its importance in psychology's history, it is now called classical conditioning (also known as respondent conditioning).

Put "T" for true and "F" for false statements.

1. Most of daily activities of humans are learned behavior.

2. By reinforcing correct response, we can teach animals to do things.

3. Reflexes are categorized as simple form of inborn traits.

4. In classical conditioning to reserve a conditioning, conditioned stimulus should inhibited.

5. According to Pavlov, unconditioned stimuli usually create reflex responses.

Choose a, b, c, or d which best completes each item.

1. According to most psychologists, learning is in behavior.

a. A permanent change

b. A relatively permanent change

c. A temporary change

d. A short-term change

2. Complex behavioral patterns ascribed to all species are combination of

a. Both reflexes and learned behavior

b. Both fixed action patterns and reflexes

c. Neither reflexes nor learned behavior

d. Inborn behavior only

3. Theories of learning can serve as a/an. for solving practical problems.

a. index

b. standard

c. handle

d. guide

4. The result of learning must be translated into behavior.

a. Visible

b. Overt

c. Observable

d. Discernable

5. Learning is one of the most important area in psychology and an extremely difficult to define.

a. Idea

b. Notion

c. Doctrine

d. Concept

Answer the following questions.

1. What is a good definition of learning accepted by most psychologists?

2. Who did introduce the theory of conditioning learning?

3. What is the difference between reflex and instinct? 
Fill in the blanks with the appropriate words.

Distinctive feelings puzzle layman observe overlap argued

In an important sense, each of us is a psychologist. We all human behavior, attempt to predict it, understand it and control it. We not only observe and over our own behavior, but also attend to what those about us are doing and why. While these everyday observations clearly . The activities of the professional psychologists, we would not call them psychological inquiries because they lack the features of science. Psychologists and

define behaviors in much the same way. In the past, they have over whether internal, subjective, mental images, thoughts and are within the domain of psychology.

\section{APPENDIX B}

Read the text carefully and translate it into Persian.

\section{Structuralism}

In the United States, Wundt's idea gave rise to a school of thought called structuralism. They hoped to develop a sort of "mental chemistry" by analyzing experience into basic elements or "building blocks". In this approach a structuralist may heft an apple, and then decide that he or she had experience the elements of color, roundness, and weight. So, it soon became evident that introspection left much to be desired as a way of answering psychological questions. The most troublesome problem was simply this: introspectionists frequently disagreed. If two researchers came up with different lists of elementary taste sensations, who was to say which was right? Despite such limitations, "looking inward" is still a part of modern psychology. The study of hypnosis, meditation, drug effects, problem solving and many other topics would be incomplete without reports of subjective experiences.

\section{Expectations}

A psychology professor, James Harword (2010), one arranged an experiment in which a guest lecturer taught his class. Half of the student were given a page of notes that describe the lecturer as a "rather cold person, industrious, critical, practical, and determined." The other students received notes describing him as a "rather warm person, industrious, critical, practical, and determined." Students who received the "cold" perceived the lecturer as unhappy and irritable, and were not volunteer in the class discussion. Those who got the "warm" description saw the lecturer as happy, good-natured and they actively took part in discussion with him.

\section{Attention}

Very intense stimuli are attention. They are brighter, louder, or larger tend to capture attention. A gunshot in a library would be hard to ignore. Repetitious stimuli, Repetitious stimuli, Repetitious stimuli are attention-getting. A dropping faucet at night makes little noise by normal standard, repetition it may become as attention-getting as a single sound many times louder. Attention is also frequently related to contrast or change in stimulation. Change is the most basic source of it.

Citation: Somayeh Sahebalzamani and Mohammad Golshan. The Impact of Jigsaw and Listen-and-do Tasks on English for Specific Purposes (ESP) Learners' Reading Comprehension and Translation in Psychology Course. International Journal on Studies in English Language and Literature (IJSELL), vol 5, no. 10, 2017, pp. 47-58. doi:http://dx.doi.org/10.20431/2347-3134.0510007.

Copyright: () 2017 Authors. This is an open-access article distributed under the terms of the Creative Commons Attribution License, which permits unrestricted use, distribution, and reproduction in any medium, provided the original author and source are credited. 